\title{
A Study of Analysis for Noise Environment and Hearing Loss of Army Aviation Pilots
}

\author{
Kyucheol Ko ${ }^{1}$, Oyonghyeok Lee ${ }^{1}$, Jinsook Kim²,3, Taewon Lee ${ }^{4}$, Yerim Shin ${ }^{2}$, Hyesook Lee ${ }^{5}$ \\ ${ }^{1}$ Republic of Korea Army Aviation School Combat Development Department, Nonsan, Korea \\ 2Department of Speech Pathology and Audiology, Graduate School, Hallym University, Chuncheon, Korea \\ ${ }^{3}$ Division of Speech Pathology and Audiology, College of Natural Sciences, Hallym University, Chuncheon, Korea \\ ${ }^{4}$ Division of Mathematical Sciences, Sejong Campus, Korea University, Sejong, Korea \\ ${ }^{5}$ Republic of Korea Force Aerospace Medical Center, Cheongju, Korea
}

Received: November 16, 2020

Revised: January 12, 2021

Accepted: February 10, 2021

\section{Correspondence:}

Jinsook Kim, FAAA, PhD

Division of Speech Pathology and

Audiology, College of Natural Sciences,

Hallym University,

1 Hallymdaehak-gil,

Chuncheon 24252, Korea

Tel: +82-33-248-2213

Fax: +82-33-256-3420

E-mail: jskim@hallym.ac.kr
Purpose: The hearing condition of pilots and the level of noise of helicopter were of interest. This study aimed to analyze the noise environment and hearing loss of the pilots of Korean army aviation. Methods: A total of 242 pilots who did not have any middle ear problems or other ear diseases were selected: 34, 69, 70, and 69 from the age group 20,30, 40, and 50, respectively. The physical examination records of hearing test from 2015 to 2019 were analyzed. The noise environment was measured at the two indoor positions of pilot and crew and one outside position which was $1 \mathrm{~m}$ away from the 8 helicopters owned by Korean army aviation: 500MD, UH-1H, UH-60, KUH-1, AH1S, BO-105, CH-47, AH-64. Results: The thresholds of pilots were statistically different in term of frequency, age, and flight time $(p<0.05)$. The range of measured noise level of helicopters at the position of pilot, crew, and outside were 88.6 (AH-1S)-104.1 dB A (CH-47), $93.9(\mathrm{UH}-1 \mathrm{H})-108.6 \mathrm{~dB}$ $\mathrm{A}(\mathrm{CH}-47), 105$ (500MD, AH-1S)-109 dB A (AH-64). When compared hearing thresholds of the pilots to normal groups according to age groups, they were higher at $6 \mathrm{kHz}$ and lower at $0.5 \mathrm{kHz}$ for all age groups. Conclusion: The hearing thresholds of Korean army aviation pilots increased as age and flight time were increased while showing the typical noise-induced hearing loss with high frequency involvement. We suggest that hearing protection education should be provided and the appropriate hearing conservation program should be established for pilot hearing health care in the future.

Key Words: Army aviation pilots, Flight time, Noise environment, Hearing thresholds.

\section{INTRODUCTION}

육군항공 조종사들은 1950 년 전쟁 중 육군항공과로 창설된 이후 70 년이 지난 현재 육군항공 병과로 맥을 이어 초심을 유 지하며, 지금도 조국수호를 위해 한반도의 전 영공에서 불철주 야 위국헌신의 자세로 임무를 완수하고 있다. 지난 7월에는 52 년간 육군항공의 핵심 기동전력이었던 UH-1H 헬기가 무려 79 만 시간 동안 1 억 4,600 만 $\mathrm{km}$ 의 거리를 비행하고 퇴역하기도 했다(Lee, 2020). 육군항공 병과에서 운용하는 헬기는 공군의 주 기종인 고정익(fixed-wing)항공기와 달리, 로터가 조종석의 머리 위에 위치한 회전익(rotary-wing)항공기여서, 로터가 회전 하며 공기를 가로질러 생기는 aerodynamic shock sound라 불

(c) This is an Open Access article distributed under the terms of the Creative Commons Attribution Non-Commercial License (https://creativecommons.org/licenses/by-nc/4.0) which permits unrestricted non-commercial use, distribution, and reproduction in any medium, provided the original work is properly cited.
리는 충격음이 지속적으로 발생한다. 또한 육군항공 조종사들 은 대부분 1년 이상 지상부대 근무가 의무적이어서 사격훈련이 필수적이므로 사격 관련 소음에도 노출된 경험이 있다. 따라서 육군항공 조종사들은 사격 관련 소음으로 취약해진 청각시스 템으로, 비행 중 소음이 더 발생하는 항공기를 운용하고 있어 소음성 난청 발생이 더 취약하다고 할 수 있다.

일반적으로 조종사들은 비행 중 항공기에 탑재된 서너 개의 무전기를 통해 관제탑, 인접 항공기, 지상부대 등의 요원과 교 신하여야 하고, 때로는 다른 항공기의 교신 내용도 감청해서 그 내용을 인지해야만 한다. 그러나 헬기에서 발생하는 소음은 이 러한 임무 수행을 방해하고, 더 나아가 조종사들의 청력에도 상 당한 영향을 미칠 것으로 추정된다. 1977년 3월 스페인령 테네 리페 섬 로데오 공항에서 발생한 사고의 사례는 조종사들의 청 력 상태와 소음 속의 교신 상황이 얼마나 열악하고 중요한지 확 인할 수 있는 사례이다. 안개로 인해 시정이 좋지 않은 상태에서 
관제탑과 항공기 간 불분명한 의사소통으로 583 명이 사망하고 61명이 부상 당한 항공 사상 최악의 단일 사고로 기록되었는 데, 항공기 두 대가 활주로상에서 충돌한 사고로 주변 소음과 조종사의 부정확한 어음 이해 능력이 사고의 원인으로 지목되 었다. 구체적으로 관제탑에서 교신으로 전달한 "OK (2초간 무 응답) Standby for taking off. I will call you again" 내용을 조 종사는 심리적 부담과 무전기 잡음으로 “ $\mathrm{OK}$ ”라는 한 마디만 이해하였고, 그 이후 내용을 알아들을 수 없었기 때문에 이륙 을 위해 활주를 하다 동일 활주로에서 이동하는 항공기와 충 돌하게 된 사고였다(Hawkins, 1993). 이와같이 항공 조종사의 의사소통 환경은 매우 중요하며 이러한 의사소통 환경이 마련 되지 않을 시 치명적 사고로 이어질 수 있다.

소음과 관련된 의사소통 환경과 더불어, 소음 때문에 영향을 받을 수 있는 육군항공 조종사들의 청력 상태도 구체적으로 확인해야 할 필요성이 대두되었다. 육군항공 조종사들의 청력 상태는 매년 정밀 신체검사를 통해 점검을 하고 있으나, 국내에 서는 육군항공 조종사들의 의사소통 능력을 방해하는 헬기에 서 발생하는 소음과 연계하여 분석되지 않고 그에 따른 적절한 조치도 부족한 실정이다. 국내 헬기 소음과 조종사 관련 자료는 헬기 소음이 조종사의 청력 및 교신에 미치는 영향을 분석한 연 구내용으로 처음 제시되었다. 연구결과는 세 가지인데, 첫째, 조 종실의 항공기 소음은 약 $100 \mathrm{~dB} \mathrm{~A}$ 로 추정되고, 헬멧으로 일부 소음은 차단되지만 여전히 소음은 조종사의 청력과 교신 시 어 음 이해도에 영향을 미친다. 둘째, 청력 보호와 조종사의 의사소 통 능력을 정상적으로 유지하기 위해 귀마개를 착용해야 한다. 셋째, 사용 중인 귀마개는 청력 보호에는 좋으나 $2 \mathrm{kHz}$ 이상의 음성신호를 $30 \mathrm{~dB}$ 정도 차음하여 어음 이해도를 저하시키는 원인이 되므로, $1 \mathrm{kHz}$ 이상 주파수 대역에서 약 $25 \mathrm{~dB}$ 정도 차 음할 수 있는 귀마개를 사용하여야 한다(Ko et al., 1999). 그 외, 공군 헬기 조종사의 청력손실 관련 연구에서 연령과 비행시간 이 청력손실에 영향을 주며, 오른쪽 청력보다 왼쪽 청력이 더 저하되는 현상을 보였다(Lim et al., 2011; Park \& Kim, 2003). 공군 조종사의 청력손실과 관련성이 있는 요인으로는 과거 진 료 경험, 식전 혈당, 이명, 가족력, 외상, 체질량 지수, 이완기 혈 압, 콜레스테롤 수치, 흡연 등 건강 관련 사항이 확인되었고, 관 련성이 없는 요인으로 비행 기종과 여가활동 등이 조사되었다 (Jeong et al., 2013).

해외에서의 헬기 조종사 관련 연구는 육군과 공군에서 다양 한 주제로 시행되었다. 최근 발간된 미국의 비행 요원의 훈련 보고서에서는 헬기 조종사들의 청력손실을 예방하기 위한 방 법으로 보호구 착용의 중요성을 강조하고 한 번의 긴 비행시간 보다 자주 쉬어가며 여러 번의 짧은 비행시간을 권고하고 있다 (United States Government US Army, 2018). 핀란드의 연구
에서도 한 번의 비행 전후 육군항공 조종사의 청력을 측정하였 을 때, 일시적 청력역치 증가(temporary threshold shift, TTS) 는 관찰할 수 있었으나 청력 정도의 변화는 미미하였고, 산업근 로자보다 소음성 난청의 위험에 더 안전하다고 보고하였다 (Kuronen et al., 2003; Kuronen et al., 2004). 그러나 국내의 공군 헬기 조종사들과 마찬가지로 연령과 비행시간이 증가할 수록 청력손실이 발생할 가능성이 높아진다고 보고한 영국 해 군(Jones, 1988), 태국(Jaruchinda et al., 2005), 프랑스(Raynal et al., 2006) 조종사 대상의 연구들도 있었다. 조종사의 연령과 비행시간을 비교한 두 개의 연구에서 공통적으로 연령보다 비 행시간이 더 영향을 주는 것으로 나타났다(Fitzpatrick, 1988; Owen, 1996). 미국의 한 연구에서 1997년에서 2011년까지 육 군, 해군, 공군, 해병대의 조종사들을 대상으로 감각신경성 난 청의 발생률을 비교 분석하였는데, 육군은 $19.6 \%$, 공군은 $14.7 \%$, 해군은 $7.2 \%$, 해병대는 $7.3 \%$ 로 육군 조종사들의 발생률 이 가장 높았다(Orsello et al., 2013). 프랑스의 한 연구에서는 비행에 운용되는 기종별로 조종사들의 청력에 미치는 영향 정 도를 연구하였을 때, 수송기보다 전투기와 헬기가 청력에 더 큰 영향을 주는 것으로 보고되었다(Raynal et al., 2006). 그러나 민간여객기가 헬기보다 청력에 미치는 영향이 더 크다는 노르 웨이의 연구결과도 보고되었는데(Wagstaff \& Årva, 2009), 이 는 헬기 조종사가 귀를 완전히 덮는 형태의 귀마개를 사용하여 차음 효과가 좋았기 때문이라고 하였다. 그 외 소음이 청력손실 은 물론 이명 발생의 위험 요인 중 하나라고 지목한 스웨덴의 연구결과(Lindgren et al., 2009)와 흡연이 청력손실을 발생시키 는 위험 요인 중 하나라고 지목한 핀란드의 연구결과(Toppila et al., 2000)도 비행 소음과 관련이 있다.

이러한 군 항공기의 소음 문제는 군부대가 위치한 주변의 민 간 피해로도 연계될 수 있다. 그 예로 마을 한복판에 위치한 육 군 항공단의 헬기 소음으로 60 년 이상 피해를 입고 있는 내용 이 기사화되었다(Yoon, 2020). 구체적으로 헬기 이착륙 진동으 로 기왓장이 내려앉고 담벼락에 균열이 발생하며 헬기 소음으 로 주민들에게 이명, 정신착란, 집중력 저하, 불면증 등 건강 이 상이 나타나고 소와 같은 가축의 발육부진과 유산 등으로 생 업에도 지장이 있다고 하였다. 또한 전주에서는 소음 측정 방식 의 논란과 그에 따른 항공대대의 이전 관련 논란이 기사화된 적도 있었다(Kim, 2016). 이러한 군 비행장과 철원과 포천의 군 사격장의 소음 피해로, 2019년에는 군 관련 소음 발생 방지와 민간인의 피해 보상 내용을 다룬 군소음법이 국회 본회의를 통 과하였다(Kim, 2019). 최근에는 군 공항 주변 주민은 소음 피 해 소송을 하지 않아도 보상을 받을 수 있도록 '군사기지 및 군 사시설 주변 지역 소음 피해 보상 및 지원에 관한 법률안이 국 회의 국방위원회에 통과되어 2020년에 군소음법이 국회 본 회 
의를 통과할 것으로 전망하고 있다(Jang, 2019).

이렇게 군 항공 관련 소음은 그 영향이 크다. 그러나 비행 관 련 소음에 더 취약할 것으로 생각되는 육군항공 병과 조종사 들의 청력 상태를 분석한 연구는 국내에 거의 없다. 더욱이 큰 소음이 발생되는 회전익을 사용하는 육군의 헬기 관련 소음 분석은 아직 이루어지지 못하고 있고, 육군항공 조종사들의 청 력 상태도 정기적인 건강 검진 외에 비행 이력이나 비행 소음과 연계되어 분석된 적이 없어 적절한 개선 방안을 제시하지 못하 고 있는 실정이다. 따라서, 본 연구는 육군항공 병과 창설 이래 최초로 조종사들이 운용하는 헬기의 소음 수준을 육군항공이 보유하고 있는 헬기 기종별로 분석하고, 육군항공 조종사들의 연령별, 비행시간대별 청력 상태를 분석하고자 하였다. 이를 바 탕으로 육군항공 병과의 소음 환경을 개선하고, 육군항공 조종 사들을 위한 적절한 보호구 선정과 착용 방법에 대한 권고안을 제시하고, 헬기 비행과 관련하여 안전한 소음 노출 정량과 적 정 시간 등을 논의하여 육군항공 조종사들의 청력 보존 방법 을 모색하고 이상적인 청력 관리 방안을 제시하고자 하였다. 이 러한 내용은 궁극적으로 육군항공 병과의 조종사 청력 보호를 극대화하고 육군항공 병과의 선진화 구현에 기여할 수 있을 것 으로 기대된다.

\section{MATERIALS AND METHODS}

\section{연구 대상}

청력 분석을 위한 대상자 선정은 2015년부터 2019년까지 공 군항공우주의료원에서 육군항공 조종사 정기 신체검사를 받은 인원들 중 비교적 비행시간의 편차가 적은 조종사를 대상으로 하였다. 육군항공 조종사 중 장교는 개인별로 비행시간에 편차 가 많아, 비행이 주 업무인 준사관 계급의 조종사를 대상으로 선 정하였다. 준사관 조종사 총 535 명 중, 중이염 등 중이 질환이 없고 최근에 정기 신체검사에서 청력 검사결과 분석이 가능한 20,30 , 40,50 대 연령에서 각각 $34,69,70,69$ 명, 총 242 명이 선정되었다.

\section{연구 방법 및 도구}

청력검사는 공군항공우주의료원이 보유한 AC40 청력검사기 (Interacoustics; Assens, Denmark)로 SAF-1400 방음실에서 실시하였다. 청력 검사기는 매년 2회 군 종합정비창을 통해 보 정을 실시하였고, 청력검사는 대한이비인후과협회에서 시행한 청각사 과정에서 자격을 취득한 인원이 실시하였다. 순음청력 역치평균은 6 분법 $(0.5+1+2+3+4+6 \mathrm{kHz} / 6)$ 을 적용하여 계산하였다. 2019년 12월 31일을 기준으로 육군항공이 보유한 8개 기종, $500 \mathrm{MD}, \mathrm{UH}-1 \mathrm{H}, \mathrm{UH}-60, \mathrm{KUH}-1, \mathrm{AH}-1 \mathrm{~S}, \mathrm{BO}-$ $105, \mathrm{CH}-47, \mathrm{AH}-64$ 를 대상으로, 각 헬기의 내부와 외부에서 소음을 측정하였다. 육군항공 병과에서 보유하고 있고 운용하 고 있는 8대의 헬기는 주로 미국, 유럽 국가, 일본 등지에서 널 리 사용되는 헬기들이다. 구체적으로 $500 \mathrm{MD}$ 는 미국에서 공격 및 정찰 헬기로 제작되어 우리나라에서는 1976년부터, UH-1H 는 미국에서 소형 기동 및 수송 헬기로 제작되어 우리나라에서 는 1968년부터, UH-60은 미국에서 중형 기동 및 수송 헬기로 제작되어 우리나라에서는 1990년부터, $\mathrm{CH}-47$ 는 미국에서 대 형 기동 및 수송 헬기로 제작되어 우리나라에서는 1988년부터, AH-1S는 미국에서 중령 공격 헬기로 제작되어 우리나라에서 는 1988년부터, BO-105는 독일에서 소형 정찰 헬기로 제작되 어 우리나라에서는 1999년부터, AH-64E는 미국에서 대형 공 격 헬기로 제작되어 우리나라에서는 2016년부터 운용되고 있 다. 그중 KUH-1은 유럽의 헬리콥터를 기반으로 우리나라에서 는 2013년에 제작되어 운용되고 있다. 조종석의 소음측정은 횡 으로 착석하는 조종석의 경우 우측 조종사를 기준으로 측정하 였고, 종으로 착석하는 조종석의 경우 후방석을 기준으로 각각 2회 측정하였다. 헬기 외측 소음은 지상에 이륙 대기 중인 헬기 를 정면에서 바라볼 때 좌측 문 $1 \mathrm{~m}$ 거리에서 측정하였다. 소 음 측정은 Hand-held Analyzer Type 2250 (Brüel and Kjær, Nærum, Denmark)을 사용하여 2분간 1/3 옥타브 밴드별 등가 소음도인 LAeq로 측정하였다.

육군항공 조종사들이 사용하는 보호구인 귀마개 성능 확인 을 위해서 현재 사용 중인 폼(foam)형 귀마개[웰킵스원더핏귀마 개 WEP-1 (Fuyang Handy Plastic; Zhejiang, China)]와 몰드
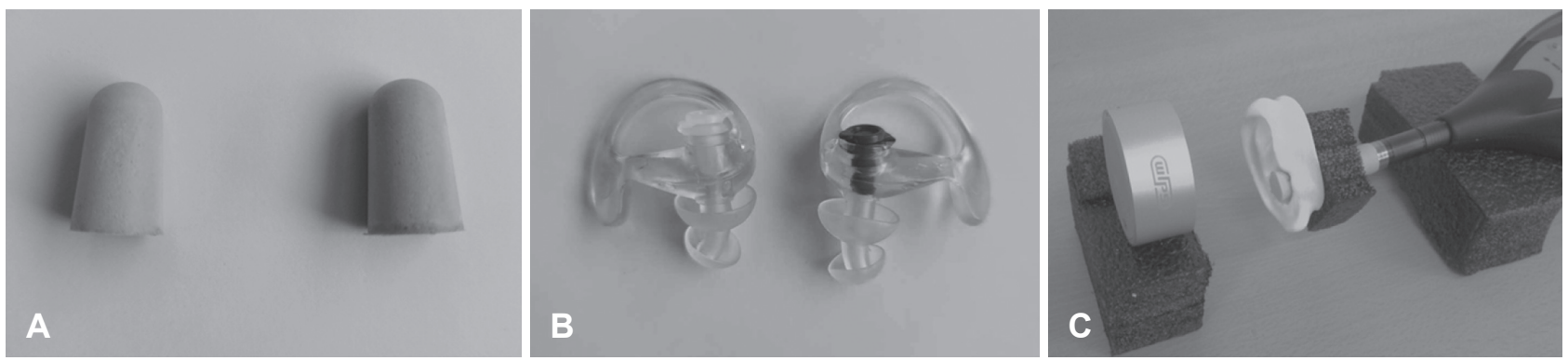

Figure 1. The features of foam (A) and molded $(B)$ earplugs and adult ear model self-conducted $(C)$ that used in the present study. 
(mold)형 귀마개[EP3 Sonic defenders (Surefire; Fountain Valley, California, USA)]와 과거에 사용했던 New Dynamics 사의 sound guard 폼형 귀마개와 $3 \mathrm{M}$ 사의 폼형 귀마개를 이용 하여 성능을 측정하였다. 정확한 성능 측정을 위해 $3 \mathrm{D}$ 프린터 로 자체 제작한 성인 평균 크기의 모형 귀에 귀마개를 장착하고 귀마개별로 2회씩 측정하여 평균값을 구하였다(Figure 1). 모형 귀는 Lass \& Woodford(2007)가 제시한 성인 평균 외이도의 총 길이와 직경을 참고하여 외이도 길이는 $3.2 \mathrm{~cm}$, 직경은 $0.8 \mathrm{~cm}$ 가 되도록 제작하였다. 차음 효과를 측정하기 위하여 소음 환경 은 약 $101.3 \mathrm{~dB}$ A로 조성하여 측정하였다. 차음 효과는 귀마개 를 착용하지 않은 상태에서 측정한 소음값에서 귀마개를 모형 귀에 착용한 상태에서 측정한 소음값을 차감하여 계산하였다. 청력 보호에 대한 관심도와 예방법, 흡연 여부 등 청력 상태에 영향을 줄 수 있는 생활 환경을 묻는 17 개 문항을 구성하여 설 문 조사를 실시하였다.

\section{통계 분석}

통계는 SAS 9.4와 SPSS 프로그램(version 21, IBM Corp., Armonk, NY, USA)을 사용하여 $t$ 검정, 이원분산분석, 다변량분산 분석, 회귀분석을 실시하였다. 모든 통계 분석의 유의성 판정은 유의수준 0.05 를 기준으로 하였다.

\section{RESULTS}

\section{주파수별, 연령별, 비행시간대별 조종사의 청력역치}

주파수에 따른 청력역치는 $0.5 \mathrm{kHz}$ 는 $8.09 \mathrm{~dB}(\mathrm{SD}: 5.6698)$, $1 \mathrm{kHz}$ 는 $9.03 \mathrm{~dB}(\mathrm{SD}:$ 6.4926), $2 \mathrm{kHz}$ 는 $10.05 \mathrm{~dB}(\mathrm{SD}: 8.7716)$, $3 \mathrm{kHz}$ 는 $14.12 \mathrm{~dB}(\mathrm{SD}: 16.4458), 4 \mathrm{kHz}$ 는 $19.81 \mathrm{~dB}(\mathrm{SD}$ : 19.6920), $6 \mathrm{kHz}$ 는 $26.33 \mathrm{~dB}(\mathrm{SD}: 20.5425)$ 로 집단 간 통계적으 로 유의미한 차이가 나타났다 $[\mathrm{F}(5,1446)=61.119, p<0.01]$. 연 령별 청력역치는 25 29세는 $5.61 \mathrm{~dB}(\mathrm{SD}: 3.1634), 30 ~ 34$ 세는 $8.19 \mathrm{~dB}(\mathrm{SD}: 5.2814), 35$ 39세는 $11 \mathrm{~dB}(\mathrm{SD}: 6.6248), 40 \sim 44$ 세는 13.35 dB(SD: 7.1831), 45 49세는 $16.52 \mathrm{~dB}(\mathrm{SD}: 10.8798), 50 \sim 54$ 세는 $20.54 \mathrm{~dB}(\mathrm{SD}: 11.5509), 55$ 58세는 $26.59 \mathrm{~dB}(\mathrm{SD}: 12.1098)$ 였고 집단 간 통계적으로 유의미한 차이가 나타났다 $[\mathrm{F}(6,235)=$ 24.168, $p<0.01]$. 귀의 방향에 따른 청력역치를 분석하였을 때 오른쪽은 $14.51 \mathrm{~dB}(\mathrm{SD}: 12.815)$, 왼쪽은 $14.64 \mathrm{~dB}(\mathrm{SD}: 11.2305)$ 로 통계적으로 유의미한 차이는 없었다. 이를 사후분석 하였을 때 오른쪽 청력은 $0.5 \mathrm{kHz}$ 를 제외한 나머지 주파수 $1,2,3,4$ 와 $6 \mathrm{kHz}$ 에서 25 29세와 30 34세 그룹이 50 54세와 55 58세 그룹보다 유의미하게 청력역치가 낮았고, 왼쪽 청력도 모든 주 파수에서 25 29세와 30 34세 그룹이 50 54세와 55 58세 그 룹보다 유의미하게 청력역치가 낮았다. 40 44세 그룹에서는 왼

Table 1. Hearing thresholds of pilots according to age groups in $\mathrm{dB} H \mathrm{HL}$

\begin{tabular}{|c|c|c|c|c|c|c|c|c|}
\hline \multirow{2}{*}{ Frequency $(\mathrm{kHz})$} & \multicolumn{8}{|c|}{ Age groups of participants (years) } \\
\hline & $25-29$ & $30-34$ & $35-39$ & $40-44$ & $45-49$ & $50-54$ & $55-58$ & $p$-value \\
\hline \multicolumn{9}{|l|}{ Both ear } \\
\hline 0.5 & $6.76(5.28)$ & $6.93(4.25)$ & $8.01(4.92)$ & $7.29(3.40)$ & $7.43(8.30)$ & $8.60(3.38)$ & $11.57(7.13)$ & $<0.01$ \\
\hline 1 & $5.66(4.14)$ & $6.93(4.38)$ & $8.31(5.66)$ & $8.50(5.12)$ & $9.21(8.13)$ & $9.63(3.38)$ & $14.86(8.74)$ & $<0.01$ \\
\hline 2 & $4.41(3.32)$ & $5.71(3.72)$ & $7.20(7.56)$ & $8.57(6.59)$ & $10.93(9.85)$ & $14.41(8.51)$ & $19.00(9.53)$ & $<0.01$ \\
\hline 3 & $3.68(4.18)$ & $5.71(4.09)$ & $8.31(8.20)$ & $12.00(13.49)$ & $15.57(16.71)$ & $24.85(21.02)$ & $28.57(19.38)$ & $<0.01$ \\
\hline 4 & $4.12(5.18)$ & $9.21(10.65)$ & $13.82(12.60)$ & $19.14(13.81)$ & $23.79(17.71)$ & $29.71(23.08)$ & $38.57(23.63)$ & $<0.01$ \\
\hline 6 & $9.04(5.37)$ & $14.64(12.92)$ & $20.37(15.56)$ & $24.64(15.85)$ & $32.21(18.96)$ & $36.03(20.34)$ & $47.00(22.40)$ & $<0.01$ \\
\hline \multicolumn{9}{|l|}{ Right ear } \\
\hline 0.5 & $7.21(7.30)$ & $6.57(4.33)$ & $8.24(7.77)$ & $6.86(4.22)$ & $9.00(16.26)$ & $8.53(5.00)$ & $12.86(11.00)$ & 0.069 \\
\hline 1 & $6.62(6.93)$ & $6.14(4.38)$ & $8.68(7.72)$ & $8.00(5.59)$ & $10.71(16.28)$ & $8.82(3.49)$ & $16.29(13.63)$ & $<0.01$ \\
\hline 2 & $5.29(4.91)$ & $6.14(4.21)$ & $7.94(10.08)$ & $8.00(5.97)$ & $10.57(16.75)$ & $14.12(10.83)$ & $20.86(14.22)$ & $<0.01$ \\
\hline 3 & $3.53(4.69)$ & $5.71(5.71)$ & 7.79 (9.79) & $11.57(13.44)$ & $16.00(22.58)$ & $25.15(21.90)$ & $27.71(19.34)$ & $<0.01$ \\
\hline 4 & $4.26(6.29)$ & $9.29(11.39)$ & $13.24(16.42)$ & $18.00(16.99)$ & $23.86(22.56)$ & $31.18(25.62)$ & $37.86(25.42)$ & $<0.01$ \\
\hline 6 & $8.97(6.25)$ & $12.71(11.40)$ & $20.15(17.21)$ & $20.57(16.71)$ & $31.86(22.00)$ & $36.03(23.02)$ & $45.43(24.11)$ & $<0.01$ \\
\hline \multicolumn{9}{|l|}{ Left ear } \\
\hline 0.5 & $6.32(3.95)$ & $7.29(5.86)$ & $7.79(4.30)$ & $7.71(3.50)$ & $5.86(3.53)$ & $8.68(3.76)$ & $10.29(5.14)$ & $<0.01$ \\
\hline 1 & $4.71(3.47)$ & $7.71(5.73)$ & $7.94(5.79)$ & $9.00(5.79)$ & $7.71(5.05)$ & $10.44(5.42)$ & $13.43(7.45)$ & $<0.01$ \\
\hline 2 & $3.53(3.80)$ & $5.29(4.99)$ & $6.47(7.34)$ & $9.14(10.40)$ & $11.29(10.03)$ & $14.71(8.52)$ & $17.14 \quad(8.94)$ & $<0.01$ \\
\hline 3 & $3.82(4.27)$ & $5.71(5.44)$ & $8.82(8.71)$ & $12.43(14.92)$ & $15.14(17.55)$ & $24.56(22.41)$ & $29.43(22.71)$ & $<0.01$ \\
\hline 4 & $3.97(5.04)$ & $9.14(10.95)$ & $14.41(14.02)$ & $20.29(15.86)$ & $23.71(20.84)$ & $28.24(24.40)$ & $39.29(25.21)$ & $<0.01$ \\
\hline 6 & $9.12(7.33)$ & $16.57(15.52)$ & $20.59(17.61)$ & $28.71(19.57)$ & $32.57(24.05)$ & $36.03(20.52)$ & $48.57(24.81)$ & $<0.01$ \\
\hline
\end{tabular}

Values are presented as mean (standard deviation) 
쪽 귀의 청력이 오른쪽 귀의 청력보다 유의미하게 높은 것으로 나타났다(Table 1, Figure 2).

비행시간에 따른 청력역치는 999시간 이하 그룹은 7.70 $\mathrm{dB}(\mathrm{SD}$ : 5.1012), 1,000 2,999시간 그룹은 $12.74 \mathrm{~dB}(\mathrm{SD}$ : 7.0153), 3,000 4,999시간 그룹은 $20.59 \mathrm{~dB}(\mathrm{SD}: 12.9118), 5,000$ 시간 이 상 그룹은 $23.20 \mathrm{~dB}(\mathrm{SD}: 11.7584)$ 로 집단 간 통계적으로 유의
미한 차이가 나타났다 $[\mathrm{F}(3,238)=40.263, p<0.01]$. 이를 사후 분석하였을 때 $0.5 \mathrm{kHz}$ 를 제외한 모든 주파수에서 999시간과 1,000 2,999시간 그룹이 3,000시간과 5,000시간 그룹보다 청력 역치가 유의미하게 낮았다. 3,000 4,999시간 그룹에서만 왼쪽 청력이 오른쪽 청력보다 유의미하게 높은 것으로 나타났다(Table 2, Figure 3). 연령 $\times$ 주파수, 연령 $\times$ 비행시간, 주파수 $\times$
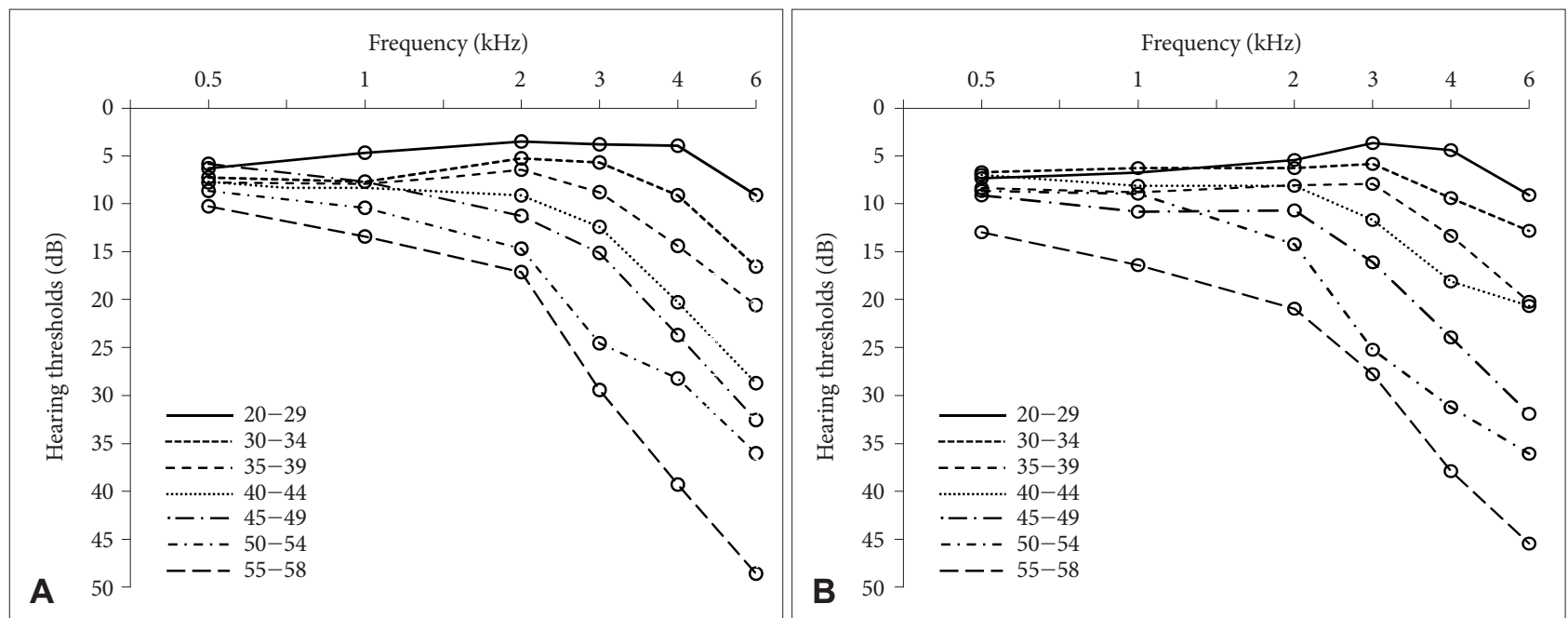

Figure 2. Hearing thresholds of pilots according to age group. The left graph (A) indicates the result of left ear and the right graph (B) indicates the result of right ear.

Table 2. Hearing thresholds of pilots according to flight time in hours at $\mathrm{dB} H \mathrm{HL}$

\begin{tabular}{|c|c|c|c|c|c|}
\hline \multirow{2}{*}{ Frequency $(\mathrm{kHz})$} & \multicolumn{5}{|c|}{ Flight time of participants (hours) } \\
\hline & $\leq 999$ & $1,000-2,999$ & $3,000-4,999$ & $\geq 5,000$ & $p$-value \\
\hline \multicolumn{6}{|l|}{ Both ear } \\
\hline 0.5 & $6.90(4.54)$ & $7.58(4.17)$ & $9.07(7.85)$ & $9.86(6.29)$ & 0.013 \\
\hline 1 & $6.64(4.48)$ & $8.17(5.27)$ & $11.40(7.62)$ & $12.07(7.79)$ & $<0.01$ \\
\hline 2 & $5.37(4.83)$ & $8.38(6.38)$ & $14.42(11.22)$ & $16.20(8.85)$ & $<0.01$ \\
\hline 3 & $5.49(5.79)$ & $11.08(11.58)$ & $22.15(21.59)$ & $25.43(18.97)$ & $<0.01$ \\
\hline 4 & $7.96(9.30)$ & $17.83(13.47)$ & $29.19(22.96)$ & $34.18(22.66)$ & $<0.01$ \\
\hline 6 & $13.85(11.86)$ & $23.42(16.24)$ & $37.33(21.26)$ & $41.49(21.63)$ & $<0.01$ \\
\hline \multicolumn{6}{|l|}{ Right ear } \\
\hline 0.5 & $6.72(5.59)$ & $7.67(6.34)$ & $10.35(15.06)$ & $10.77(9.47)$ & 0.053 \\
\hline 1 & $6.67(5.69)$ & $7.92(6.85)$ & $12.21(14.61)$ & $13.08(11.81)$ & $<0.01$ \\
\hline 2 & $5.86(5.35)$ & $8.00(7.98)$ & $16.05(17.79)$ & $16.25(12.28)$ & $<0.01$ \\
\hline 3 & $5.23(6.42)$ & $10.25(12.12)$ & $24.19(25.68)$ & $24.33(18.87)$ & $<0.01$ \\
\hline 4 & $7.41(9.52)$ & $17.67(17.11)$ & $32.21(28.87)$ & $32.31(22.98)$ & $<0.01$ \\
\hline 6 & $12.53(11.02)$ & $21.42(17.25)$ & $39.30(25.83)$ & $38.85(22.35)$ & $<0.01$ \\
\hline \multicolumn{6}{|l|}{ Left ear } \\
\hline 0.5 & $7.07(4.86)$ & $7.50(3.85)$ & $7.79(4.13)$ & $8.94(4.89)$ & 0.125 \\
\hline 1 & $6.61(5.09)$ & $8.42(5.71)$ & $10.58(6.38)$ & $11.06(6.74)$ & $<0.01$ \\
\hline 2 & $4.89(5.86)$ & $8.75(8.91)$ & $12.79(10.14)$ & $16.15(8.78)$ & $<0.01$ \\
\hline 3 & $5.75(6.58)$ & $11.92(13.99)$ & $20.12(20.77)$ & $26.54(22.57)$ & $<0.01$ \\
\hline 4 & $8.51(11.18)$ & $18.00(15.41)$ & $26.16(20.61)$ & $36.06(26.69)$ & $<0.01$ \\
\hline 6 & $15.17(14.72)$ & $25.42(19.73)$ & $35.35(21.83)$ & $44.13(24.99)$ & $<0.01$ \\
\hline
\end{tabular}

Values are presented as mean (standard deviation) 
비행시간, 연령 $\times$ 주파수 $\times$ 비행시간의 상호작용을 분석하였 을 때, 연령 $\times$ 비행시간의 상호작용 효과만 통계적으로 유의미 하였다 $[\mathrm{F}(4,1368)=5.398, p<0.01]$.

육군항공 조종사들은 초임 학생조종사와 임관 후 적용하는 청력 통과 기준이 다르다. 초임 학생조종사의 청력검사 합격 기 준은 '기준 I'이라 하는데 $0.5,1,2,3,4,6 \mathrm{kHz}$ 별로 $25,25,25$, $35,45,45 \mathrm{~dB}$ HL이다. 약 7개월의 비행 교육 과정을 수료하고 조종사로 임관(명)된 후 매년 정기 신체 검사 시 청력의 통과 기준은 '기준 II'라 하고 $0.5,1,2,3,4,6 \mathrm{kHz}$ 별로 $35,35,35$, $45,45,45 \mathrm{~dB} \mathrm{HL}$ 이다. '기준 I'을 적용하여 통과한 경우에만 임관이 될 수 있어, 임관 후 '기준 II’를 적용한 조종사들의 청력 결과를 분석하여 임관 후 청력의 변화를 추정할 수 있다. 최근 1년 이내에 실시한 신체검사에서 59명(24.3\%)이 '기준 II'를 통 과하지 못하였는데, 연령이 증가할수록 기준을 통과하지 못하 는 경우가 증가하는 것으로 나타났다(Table 3). 주파수별 통과 여부를 분석하였을 때, 25 29세 그룹의 1명을 제외한 58명이 6 $\mathrm{kHz}$ 에서 양측 귀 모두 '기준 II'를 통과하지 못하였다. 50 54세 와 55 58세 그룹에 속한 34명 모두 $4 \mathrm{kHz}$ 의 청력역치도 통과 하지 못하여 연령이 증가할수록 고주파수 대역의 청력이 저하 되는 것을 확인할 수 있었다.

\section{헬기 기종별 소음 수준과 보호구의 차음 효과}

측정된 소음 레벨은 조종석 기준으로 88.6 104.1 dB A였다. 소음 수준은 $\mathrm{AH}-1 \mathrm{~S}$ 가 $88.6 \mathrm{~dB}$ A로 가장 낮았고 $\mathrm{CH}-47$ 이 104.1 dB A로 가장 높았다. 승무원석에서는 UH-1H가 93.9 $\mathrm{dB}$ A로 가장 낮았고 $\mathrm{CH}-47$ 가 $108.6 \mathrm{~dB}$ A으로 가장 높았다. 외부 $1 \mathrm{~m}$ 거리에서 측정한 소음은 $500 \mathrm{MD}$ 와 $\mathrm{AH}-1 \mathrm{~S}$ 가 105 $\mathrm{dB}$ A로 가장 낮았고 $\mathrm{AH}-64$ 가 $109 \mathrm{~dB}$ A로 가장 높았다. 평균 수치로 분석할 때 소음 수준은 조종석, 승무원석, 외부 $1 \mathrm{~m}$ 의 순으로 높게 나타났다(Table 4).

육군항공 조종사들이 사용하고 있는 보호구인 귀마개가 정 상적으로 기능을 발휘하고 있는지를 확인하기 위해, 3D 프린터 를 이용하여 성인 기준 귀 모형을 제작하여 현재 사용 중인 귀 마개 2종과 과거사용 귀마개 2종의 성능을 측정하였다. 측정 환 경은 약 $101.3 \mathrm{~dB} \mathrm{~A}$ 의 소음을 조성한 상태에서 각 귀마개의 차 음효과를 측정하였다. 각 귀마개의 차음효과는 현재 사용 중인 폼형과 몰드형 귀마개는 $28.1 \mathrm{~dB}$ A와 $32.6 \mathrm{~dB}$ A가 차음되었고, 과거에 사용하였던 귀마개 폼형 2종은 $17.7 \mathrm{~dB} \mathrm{~A}$ 와 $33.3 \mathrm{~dB} A$ 이 차음되었다.

\section{조종사와 일반인의 청력역치 비교 분석}

조종사와 일반인들의 청력역치를 비교하기 위하여 선행연구 (Lee et al., 2003)에서 구분한 연령의 네 그룹, 25 34세, 35
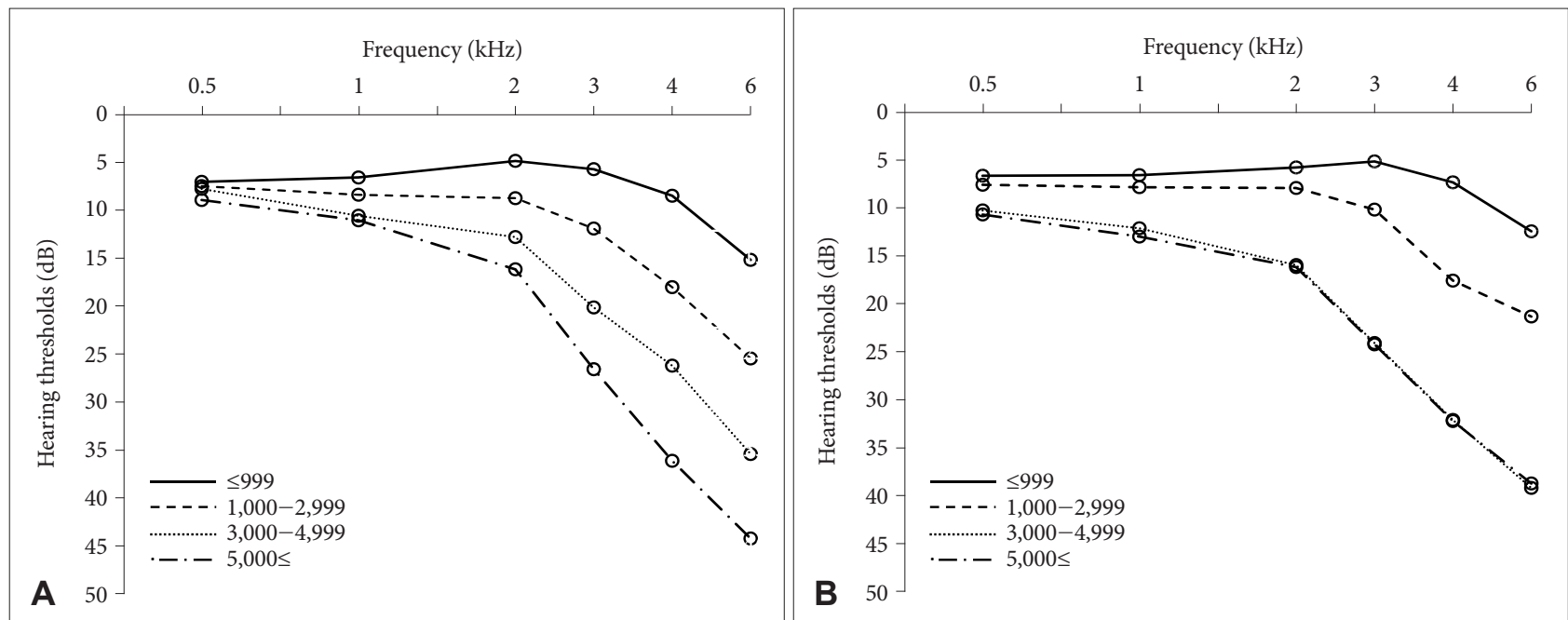

Figure 3. Hearing thresholds of the pilots according to flight time in hours at $\mathrm{dB} H \mathrm{HL}$. The left graph $(\mathrm{A})$ indicates the result of left ear and the right graph (B) indicates the result of right ear.

Table 3. Results of helicopter pilot selection adjusting standard II

\begin{tabular}{lcccccccc}
\hline & \multicolumn{7}{c}{ Age groups of participants (years) } \\
\cline { 2 - 9 } & $25-29$ & $30-34$ & $35-39$ & $40-44$ & $45-49$ & $50-54$ & $55-58$ & Total \\
\hline Case & 34 & 35 & 34 & 35 & 35 & 34 & 35 & 242 \\
Failure case & 1 & 1 & 5 & 6 & 12 & 14 & 20 & 59 \\
Failure rate (\%) & 2.9 & 2.8 & 14.7 & 17.1 & 34.2 & 41.1 & 57.1 & 24.3 \\
\hline
\end{tabular}


Table 4. The noise measurement according to types of helicopters in dB A

\begin{tabular}{lccccccccc}
\hline \multirow{2}{*}{ Measurement location } & \multicolumn{10}{c}{ Helocopter types } \\
\cline { 2 - 10 } & $500 \mathrm{MD}$ & UH-1H & UH-60 & KUH-1 & AH-1S & BO-105 & CH-47 & AH-64 & Mean \\
\hline Pilot & 101.4 & 92.5 & 92.1 & 94.1 & 88.6 & 94.4 & 104.1 & 98.1 & 95.6 \\
Crew & - & 93.9 & 94.7 & 98.1 & - & - & 108.6 & - & 98.8 \\
Outside (1 m) & 105 & 108 & 108 & 107 & 105 & 107 & 106 & 109 & 106.8 \\
\hline
\end{tabular}
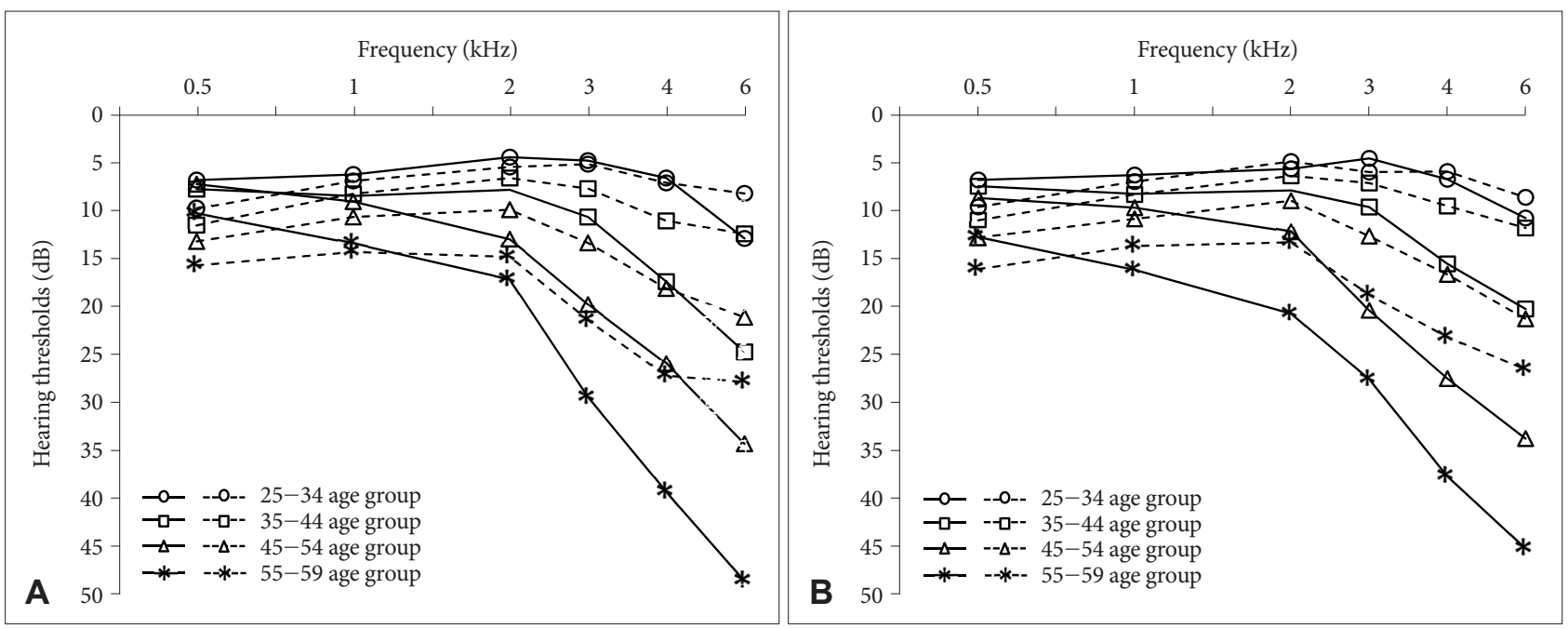

Figure 4. Hearing threshold comparison between pilot and normal hearing groups according to four age groups. The solid lines indicate the hearing thresholds of pilot group and the dotted lines indicate the hearing thresholds of normal hearing group from the previous study (Lee et al., 2003). The left (A) and right (B) graphs show thresholds of left and right ears.

34세, 45 54세, 55 59세로 재조정하여 분석하였다. 조종사와 일반인의 청력역치 차이는 연령별, 주파수 대역별로 다르게 나 타났다. 비교 분석은 연령대별 조종사의 청력역치에서 일반인 의 청력역치를 뺀 값을 사용하였다. 따라서 양수는 조종사의 청력역치가 더 큰 값으로 조종사의 청력역치가 일반인보다 더 나쁜 것을 의미하며, 음수는 조종사의 청력역치가 더 적은 값 으로 조종사의 청력역치가 일반인보다 더 좋은 것을 의미한다. 모든 연령 그룹에서 $6 \mathrm{kHz}$ 결과가 모두 양수로 조종사들의 청 력역치가 더 높았고, 특히 55 59세 그룹은 오른쪽과 왼쪽의 역 치 차이가 $18.72 \mathrm{~dB}$ HL과 $20.77 \mathrm{~dB}$ HL로 상당한 차이를 보였 다. 또한 모든 연령 그룹에서 $0.5 \mathrm{kHz}$ 의 결과는 모두 음수로 조종사들의 청력역치가 더 낮아서 청력역치가 더 좋은 것으로 나타났다(Figure 4, Table 5). 이 자료로 회귀분석을 실시한 결 과 모든 연령대에서 $0.5 \mathrm{kHz}$ 와 $1 \mathrm{kHz}$ 의 그래프 기울기가 내려 가거나 수평이어서 연령이 증가하여도 $0.5 \mathrm{kHz}$ 와 $1 \mathrm{kHz}$ 에서 의 조종사의 청력은 일반인의 청력보다 좋거나 비슷한 것으로 나타났다. 그러나 $2 \mathrm{kHz}$ 부터 연령대가 높아질수록 그래프 기 울기가 조금씩 상승하는 경향을 보이다가 $6 \mathrm{kHz}$ 에서는 가장 상승하는 그래프를 나타내었다. 따라서 연령이 증가할수록 청 력역치의 차이가 더 커졌고 이러한 차이는 고주파수일수록 더 커지는 것으로 나타났다(Figure 5).
비행시간에 따른 조종사의 청력역치를 선행연구에서 제시된 일반인의 네 개 연령 그룹의 청력역치(Lee et al., 2003)와 비교 하여 1 시간 비행시 조종사의 청력역치 변화량을 기준으로 전체 비행시간에 적용하여 회귀분석하였다. 회귀분석 결과 $0.5 \mathrm{kHz}$ 와 $1 \mathrm{kHz}$ 에서의 그래프는 기울기가 수평을 기준으로 내려가거 나 거의 수평과 가까워서 조종사의 청력이 더 좋거나 차이가 없는 것으로 나타났고, $2 \mathrm{kHz}$ 부터 기울기가 수평보다 조금씩 올라가는 경향을 보이다가 $6 \mathrm{kHz}$ 에서는 더 크게 올라가 비행 시간이 증가할수록 조종사의 청력역치가 일반인과 비교할 때 훨씬 높아져서 비행시간이 조종사의 청력역치에 영향을 미치는 것으로 나타났다(Figure 6).

\section{설문 응답 분석}

귀마개 착용실태와 청력 보호 관심 여부, 흡연 여부 등 생활 환경이 주요 내용이었던 설문 조사 결과, $85 \%$ 이상의 인원이 비행 중 귀마개를 착용하였으나 정확한 착용법을 잘 모르는 경 우가 많았다. 각 문항별 답변 결과는 '귀마개 착용법을 정확히 알고 계신가요?라는 문항에 84\%가 알고 있는 것으로 답변하 였으나 답변자 중 10 명을 무작위로 선정하여 정확한 착용방법 을 설명하라고 했을 때 9명이 1 2가지 항목을 누락하여 모든 내용을 알고 있지는 못한 것으로 나타났다. '비행 시 귀마개를 
Table 5. Hearing threshold difference between pilot and normal hearing groups

\begin{tabular}{|c|c|c|c|c|c|c|}
\hline \multirow{2}{*}{$\begin{array}{c}\text { Age } \\
\text { (year) }\end{array}$} & \multicolumn{6}{|c|}{ Testing frequency $(\mathrm{kHz})$} \\
\hline & 0.5 & 1 & 2 & 3 & 4 & 6 \\
\hline \multicolumn{7}{|l|}{ Right ear } \\
\hline $25-34$ & $-2.81^{* *}$ & -0.67 & 0.77 & -1.41 & 0.81 & 2.16 \\
\hline $35-44$ & $-3.56^{* *}$ & -0.06 & 1.52 & 2.51 & $6.05^{* *}$ & $8.46^{* *}$ \\
\hline $45-55$ & $-4.13^{* *}$ & -1.16 & 3.26 & $7.75^{* *}$ & $10.71^{* *}$ & $12.51^{* *}$ \\
\hline $55-59$ & -3.34 & 2.48 & $7.45^{* *}$ & $8.81^{*}$ & $14.55^{* *}$ & $18.72^{* *}$ \\
\hline \multicolumn{7}{|l|}{ Left ear } \\
\hline $25-34$ & $-2.98^{* *}$ & -0.66 & -1.02 & -0.36 & -0.50 & $4.69^{* *}$ \\
\hline $35-44$ & $-3.74^{* *}$ & 0.22 & 1.22 & 2.95 & $6.34^{* *}$ & $12.31^{* *}$ \\
\hline $45-55$ & $-5.95^{* *}$ & $-1.59^{*}$ & $3.07^{* *}$ & $6.43^{*}$ & $7.84^{* *}$ & $13.17^{* *}$ \\
\hline $55-59$ & $-5.41^{* *}$ & -0.87 & 2.34 & $8.02 *$ & $12.08^{* *}$ & $20.77^{* *}$ \\
\hline
\end{tabular}

${ }^{*} p<0.05,{ }^{* *} p<0.01$

착용하고 계신가요?라는 문항에 $95 \%$ 가 착용하고 있다, 시동 중인 항공기가 있을 때 '계류장에서 귀마개를 착용하고 계신가 요?'라는 문항에 $56 \%$ 가 착용하고 있다, '청력 보호를 위해 노력 하고 있는가요?'라는 문항에 $97 \%$ 가 노력하고 있다, '학습 중 음 악 청취나 통화를 위해 이어폰을 사용한다면 1일 이용시간은 얼마인가요?라는 문항에 $28 \%$ 가 사용하지 않는다, $71 \%$ 가 2 4 시간 정도 사용한다, '나는 평소 이어폰 사용 시 옆에서 다른 사 람이 부를 때 잘 못 듣는다'라는 문항에 $48 \%$ 가 잘 못 듣는다, '다른 사람들보다 TV 볼륨을 크게 시청하는 편입니까?'라는 문 항에 $60 \%$ 가 크게 시청한다, ‘흡연을 하십니까?’라는 문항에 $66.1 \%$ 가 흡연하지 않는다, $17 \%$ 가 10년 이상 흡연하고 있다고 각 각 답변하였다. 그 외, 현재 착용 중인 귀마개는 폼형이 $45 \%$, 몰 드형이 $38 \%$, 개인 구매품이 $17 \%$ 였고, 기타 청력 관련 손실 예 방 의견 또는 추가 의견을 제시하도록 한 문항에서 실효성 있 는 귀마개를 개발하여 보급을 확대해 주고, 청력 관련 교육 실 시를 적극적으로 해주며, 차후 귀마개 보급시 대, 중, 소 등의 사이즈를 구분해 공급하여 주기를 건의하였다.

\section{DISCUSSIONS}

본 연구 결과 육군항공 조종사들은 조종석 기준으로 $\mathrm{AH}-1 \mathrm{~S}$ 기종을 제외하고 92.1 104.1 dB A의 소음 환경에서 비행 중이 며 시동 후 점검 및 계류장에 위치해 있을 때는 105 109 dB A 의 소음환경에 노출되어 있는 것으로 밝혀졌다. 평균적으로 헬 기 내부에서는 $95 \mathrm{~dB} \mathrm{~A}$ 의 소음 환경에서, 헬기 외부에서는 106 $\mathrm{dB} \mathrm{A}$ 의 소음 환경에서 근무 중인 것으로 확인되었다. 미군 교 육 훈련 보고서에 명시된 미국 육군 헬기의 소음값과(United States Government US Army, 2018) 유사한 결과로 나타났다. 그러나 이러한 소음 레벨은 보호구를 착용하지 않은 상태에서 우리나라 산업안전보건기준 1 시간, 미군 교육 참고 기준 30 분
이내의 시간만 노출이 허용되는 소음 환경인데, 현재 육군항공 병과의 조종사, 승무원, 정비사는 매일 이러한 소음 환경에서 소음 노출의 시간적 제약 없이 생활하고 있다. 또한 비행을 하 지 않더라도 다른 항공기로부터 200 250 m 이격해 있어도 소 음 환경에 노출되어 주변 환경의 소음에도 영향을 받을 것으로 생각된다. 이는 기사화되고 이슈화된 춘천과 전주 주민의 보고에 서도 이미 알려져 있어 더욱 주의가 요구된다(Kim, 2016; Yoon, 2020). 더욱이 본 연구에서 제시된 소음 환경은 항공기 1대만 시동하는 경우로 구성하였지만 여러 대가 동시에 시동된 소음 환경에 노출될 수 있는 현실적 경우를 생각할 때 실질적 소음 환경은 더 열악할 수 있을 것으로 사료된다.

일반인과 육군항공 조종사의 연령 및 주파수별 청력 비교 결 과, $0.5 \sim 2 \mathrm{kHz}$ 까지는 전반적으로 일반인에 비해 육군항공 조 종사의 청력이 더 좋거나 비슷한 상태를 유지했으나, $3 \mathrm{kHz}$ 부 터는 45세 이상의 조종사들이 일반인보다 청력역치가 저하되 었고 $4 \mathrm{kHz}$ 와 $6 \mathrm{kHz}$ 에서는 35세 이상의 조종사들도 일반인에 비해 청력역치가 저하되는 것으로 나타났다. 또한 조종사 청력 분석 결과 '기준 II'에 따른 청력기준을 통과하지 못한 경우는 $3 \sim 6 \mathrm{kHz}$ 에서 96.6\%를 차지하고 있어 본 연구에 참여한 조종 사의 고주파수 청력손실은 매우 확실한 것으로 나타났다. 더 욱이 일반인과 육군항공 조종사들의 가장 큰 차이는 비행을 하면서 간헐적으로 소음에 노출된다는 것이다. 특이한 사례로 1 명의 조종사는 약 500 시간 정도의 최소비행시간에도 일반인 의 청력역치와 비교하였을 때 $6 \mathrm{kHz}$ 에서 왼쪽 청력역치는 6.44 $\mathrm{dB}$, 오른쪽 청력역치는 $3.95 \mathrm{~dB}$ 가 유의미하게 높은 것으로 나타 나서 한 번의 비행에도 청력에 치명적인 영향이 나타났다. 그러 나 한 번의 비행은 청력에 거의 영향이 없다는 선행연구 $\left(\mathrm{Ku}^{-}\right.$ ronen et al., 2003; Kuronen et al., 2004)가 있어 한 번이나 최소 비행시간이 청력에 미치는 영향은 사례별로 분석하여야 할 것으 로 생각된다. 

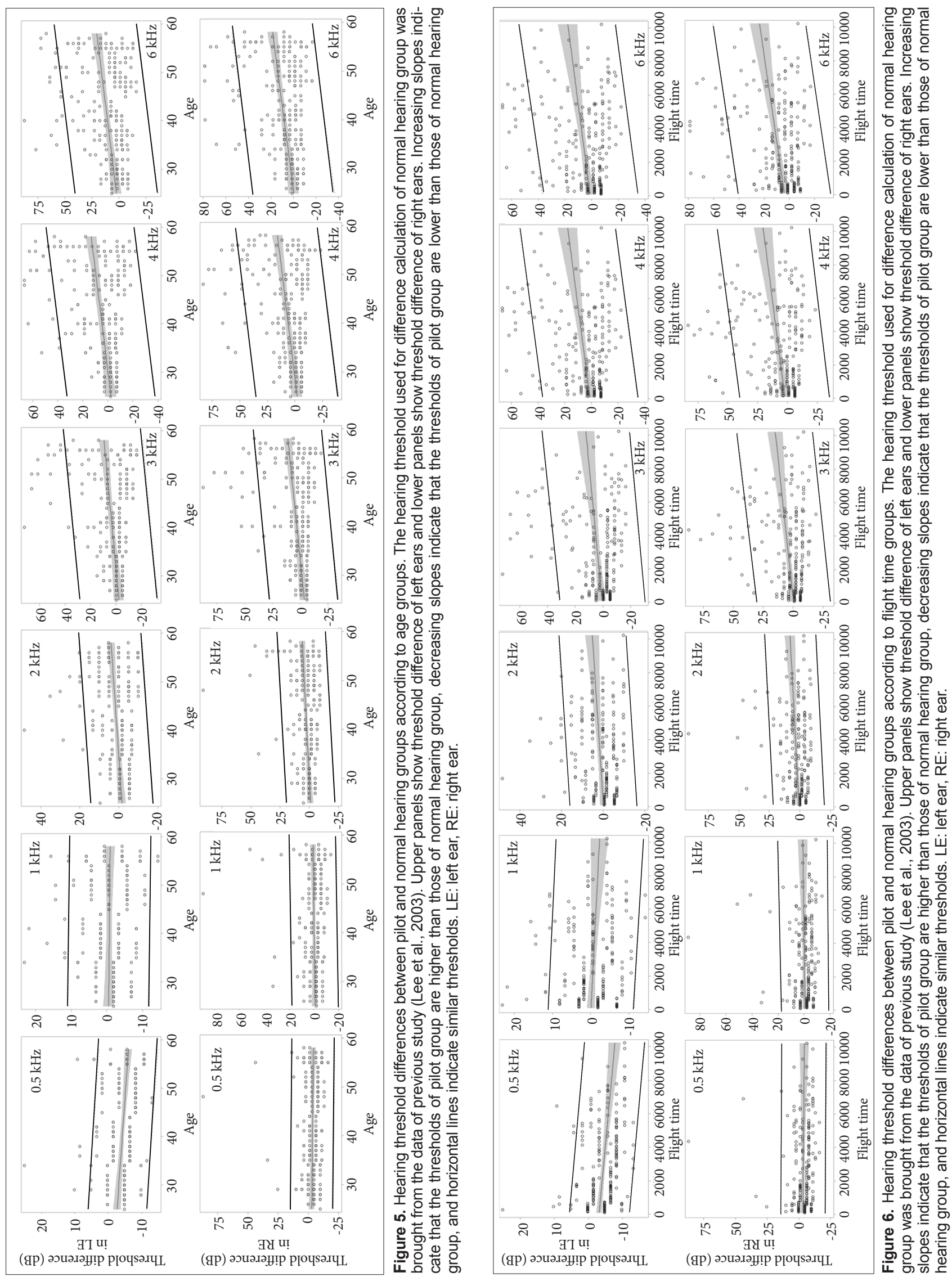
이러한 45 세 이상 조종사들의 $3 \mathrm{kHz}$ 이상 주파수 대역에서 의 청력저하 현상은, 난청으로 기록된 조종사의 평균 연령이 45.1 세였고 $3 \mathrm{kHz}$ 이상에서 4,000시간 이상을 비행한 공군 조 종사들의 청력이 유의하게 저하되었던 국내 연구(Lim et al., 2011), 미 육군 헬리콥터 조종사의 $4 \mathrm{kHz}$ 이상 고주파수 영역 의 청력저하를 보고한 연구(Fitzpatrick, 1988), 미육군 항공기 조종사의 청력역치가 연령에 따라 증가한다는 보고(Orsello et al., 2013)와 유사한 결과이다. 또한 본 연구 결과 연령과 상관없 이 $6 \mathrm{kHz}$ 에서는 조종사의 청력역치가 25 34세 연령을 제외하 고 모두 높아 국내 선행연구와 유사한 결과를 보였다(Park \& $\mathrm{Kim}, 2003)$. 항공기 소음 때문에 발생하는 고주파수 청력손실 에 대한 논리는, 간헐적으로 불규칙하게 수년간 노출되는 소음 은 저주파수 청력손실에 영향을 미치지 않으나 고주파수 청력 손실을 유발할 수 있다는 1980년대 연구에서 증명된 바 있다 (Sataloff et al., 1984). 더 나아가 항공기 소음으로 인한 고주파 수 대역의 청력손실은 $3 \mathrm{kHz}$ 이상 주파수 에너지로 생각되는 자음 음소인 /ㅅ/, /ㅆ/, /ㅈ/, /ㅉ/, /ㅊ/, /ㄷ/, /匹/, /티 등의 음소 가 포함된 자음의 이해에 영향을 미칠 것으로 생각된다(Lee et al., 2005). 따라서 조종사들의 어음이해도 능력은 일반인보다 저조할 것으로 생각되고, 이는 비행 중 교신에 영향을 미칠 수 있어 치명적 사고를 유발시키는 원인으로도 사료된다. 항공기 소음노출과 무관한 일반인의 경우도 연령 증가에 따라 청력과 어음 이해 능력도 저하된다는 보고(Huh et al., 2012; Son et al., 2000)를 고려한다면 조종사들은 노화에 따라 청력과 어음 이해도 저하가 더 가속화될 수 있으므로 노년기의 삶의 질과도 연계될 수 있어 시급한 조치가 필요하다.

군 장병들의 사격에 의한 소음성난청 연구에서(Moon, 2006) 사격 시 오른손잡이 기준 왼쪽 귀의 청력역치가 저하된다고 하였 다. 그러나 조종사의 청력역치는 왼쪽 귀의 청력이 더 저하된다는 보고(Jeong et al., 2013; Lim et al, 2011)와 왼쪽과 오른쪽 귀의 청력에 차이가 없었다는 보고(Owen, 1996)가 혼재하고 있다. 본 연구 결과는 전체적으로 분석할 때 귀의 방향에 따른 통계적 유 의성은 없었지만 사후분석에서 40 44세는 왼쪽 청력역치가 더 높았고 50대 이후의 그룹은 20대와 30대 그룹과 비교했을 때 왼 쪽의 청력역치가 더 높았다. 따라서 왼쪽 청력역치는 조종사로서 근무한 경력이 많을 것으로 추측되는 연령에서 높았던 것으로 추 정할 수 있다. 더욱이 연령과 비행시간은 통계적으로 유의미한 상 호작용을 보이는 변수로 분석되어 연령과 비행시간의 증가는 청 력에 매우 큰 부정적 영향을 미치는 것으로 생각된다.

설문 조사 결과 보호구인 귀마개의 착용법을 $84 \%$ 가 알고 있 고 $95 \%$ 의 조종사가 착용하고 있으나 착용하지 않는 이유로는 '말소리가 잘 안 들려서 교신을 잘하기 위해서' 혹은 '귀가 아파 서' 등의 이유가 있었고, 건의사항으로 사이즈별로 구분된 귀마
개 보급을 요청하였다. 또한 계류장에서는 '교육을 받은 적이 없어서', '귀찮아서', '필요성을 못 느껴서' 보호구인 귀마개를 착 용하지 않는 것으로 나타났고, 건의사항으로 청력 관리 교육과 청력보존 프로그램 구축을 요청하였다. 이는 사격 시 보호구의 착용 여부에 따라 청력 저하의 유의성이 나타났던 선행연구 결 과(Moon, 2006)를 고려할 때, 보호구인 귀마개의 보급과 적절 한 사이즈별로 구분되고 개선된 기능의 귀마개의 보급이 시급 한 것으로 생각된다. 또한 청력보존 프로그램과 청력 관리 교육 의 필요성도 이미 선행연구에서 제시되었듯이(Jeong et al., 2013) 육군의 비행장에서도 소음 레벨이 의외로 높은 계류장 에서의 보호구 착용과 구체적인 귀마개 착용법을 포함한 좀더 철저한 청력 관리 교육과 연령 및 비행시간의 증가에 따라 저 하되는 고주파수대 청력에 대한 청력보존 프로그램이 체계적 으로 실시되어야 할 것으로 사료된다. 2014년부터 소형스피커 가 장착된 communication earplug (CEP)가 부착된 신형 헬멧 을 육군항공 조종사들에게 제공하고 있다. 그러나 그 사용률 은 본 설문 대상 중 58명(27\%)으로 낮은 편인데, 그 이유는 '접 촉 부분의 통증, '더 잘 들리지 않음, ' $\mathrm{CEP}$ 를 모름, '신형 헬멧 을 보유하고 있지 않음, '고장 후 수리하지 않음, '성능 불만족'이 었다. 그러나 이러한 교신을 더 잘 할 수 있도록 고안된 신형 헬 멧에 부착된 $\mathrm{CEP}$ 의 성능과 품질 개선도 건의사항으로 기록되 어 $\mathrm{CEP}$ 성능을 향상시키고 품질을 개선하는 것은 물론, $\mathrm{CEP}$ 의 사용방법에 대한 청력관리 교육과 홍보가 필요할 것으로 사 료된다. 본 연구에 참여한 육군항공 조종사들은 흡연할 경우 하루 흡연량은 약 1 1.5갑인 것으로 나타났다. 그러나 40대 이 상 한국 성인에서 흡연과 난청의 연관성은 높고(Lee et al., 2017), 흡연 유무와 기간이 청력손실의 위험요인으로 지목된 선행연구(Jeong et al., 2013)를 고려할 때 비록 많지 않은 흡연 량이지만 청력관리 교육에 흡연과 난청의 상관관계를 포함하 는 것도 필요하다. 특히 '기준 II'를 통과하지 못한 경우를 살펴 보면, 과거나 현재의 흡연자가 많았던 점을 고려할 때 연령, 흡 연, 청력손실의 상관 여부를 분석하는 연구도 추가적으로 필요 할 것으로 사료된다.

이명이 공군의 조종사나 군 장병들에서 발생할 가능성이 높 고 소음 노출과 관련이 있다는 사실은 이미 국내외 연구에서 밝혀지고 있으며(Jeong et al., 2013; MacGregor et al., 2020; Moore et al., 2019), 실제로 육군항공 조종사 중 이명을 호소하 는 인원이 다수 존재하고 있다. 그러나 본 연구에서는 육군항 공 조종사들의 이명 관련 평가나 설문을 포함하지 못한 점이 본 연구의 커다란 제한점이라 할 수 있다. 그 외 제한점으로는 항공기 소음 외에 헬멧을 통해 외이도에 전달되는 소음을 측정 하지 못했던 점, 보호구와 귀마개의 차음 영역을 저주파수와 고주파수 대역별로 구분하여 주파수 대역별 차음 효과에 대한 
차이를 조사하지 못했던 점, 헬기 외부 소음을 생각할 때 정비 사의 청력과 조종석 바로 옆 승무원의 청력을 함께 분석하지 못했던 점, 비행 후 TTS가 발생했을 때 청력이 회복될 때까지 의 시간에 대한 체계적 연구를 못했던 점 등은 본 연구의 제한 점인 동시에 육군항공 병과의 항공기 소음과 조종사의 청력 관 련 차후 연구과제라 할 수 있다.

중심 단어 : 육군항공 조종사·비행시간·소음 환경·청력역치.

\section{Ethical Statement}

This study was approved by Institutional Review Board of the Armed Forces Medical Command (AFMC-20011-IRB-20-011).

\section{Acknowledgments}

N/A

\section{Declaration of Conflicting Interests}

There are no conflict of interests.

\section{Funding}

This research was supported by Hallym University Research Fund, 2018 (HRF-201808-008)

\section{Author Contributions}

Conceptualization: Kyucheol Ko, Oyonghyeok Lee, Jinsook Kim. Data curation: Kyucheol Ko, Taewon Lee, Hyesook Lee. Formal analysis: Kyucheol Ko, Taewon Lee. Funding acquisition: Jinsook Kim. Investigation: Kyucheol Ko, Jinsook Kim, Hyesook Lee. Methodology: Kyucheol Ko, Taewon Lee, Yerim Shin. Project administration: Oyonghyeok Lee, Jinsook Kim. Resources: Kyucheol Ko, Hyesook Lee. Supervision: Oyonghyeok Lee, Jinsook Kim. Validation: Jinsook Kim, Yerim Shin. Visualization: Jinsook Kim, Yerim Shin. Writing_original draft: Kyucheol Ko, Jinsook Kim. Writing-review \& editing: Jinsook Kim, Yerim Shin. Approval of final manuscript: all authors.

\section{ORCID iDs}

Kyucheol Ko

Jinsook Kim

https://orcid.org/0000-0002-2136-1935

https://orcid.org/0000-0003-3440-2393

\section{REFERENCES}

Fitzpatrick, D. T. (1988). An analysis of noise-induced hearing loss in Army helicopter pilots. Aviation, Space, and Environmental Medicine, 59(10), 937-941.

Hawkins, F. H. (1993). Human Factors in Flight. (1st ed.). London: Routledge.

Huh, Y. R., Lee, J., \& Lee, K. W. (2012). Effects of age on pure tone hearing thresholds and speech recognition thresholds. Audiology, 8(2), 158-164.

Jang, K. H. (2019, August 21). Compensation for Damage Will Provided without Lawsuits for Residents around the Military Airport. Suwon Daily News. Retrieved from http://www.suwonilbo.kr/news/articleView. html?idxno=201322.

Jaruchinda, P., Thongdeetae, T., Panichkul, S., \& Hanchumpol, P. (2005). Prevalence and an analysis of noise--induced hearing loss in army helicopter pilots and aircraft mechanics. Journal of the Medical Association of Thailand, 88 Suppl 3, S232-S239.

Jeong, J. A., Han, S. K., Hong, O. S., \& Kim, M. J. (2013). Prevalence and risk factors of noise-induced hearing loss among the Republic of Korea air force pilots. Journal of Military Nursing Research, 31(2), 102-117.

Jones, D. G. (1988). An audiological survey of aircrew. Journal of the Royal
Naval Medical Service, 74(1), 44-50.

Kim, S. H. (2016, February 15). Controversy Continues on How Aviation Battalion Noise is Measured in Jeonju-si. Jeonbuk News. Retrieved from http://www.jjan.kr/news/articleView.html?idxno=574202.

Kim, S. H. (2019, November 1). The Regulation Regarding Army Nosie Passed Parliamentary Law Committee. Munhwa Broadcasting Corporation. Retrieved from https://www.mbceg.co.kr/post/72107.

Ko, S., Lee, J. S., Cho, M. J., \& Seo, J. K. (1999). Proceeding of from 2nd Ergonomics Society of Korea Conference: A Study on the Effect of Helicopter Noise on Pilot's Hearing and Conversation over the Telephone. Seoul: Korea.

Kuronen, P., Sorri, M. J., Pääkkönen, R., \& Muhli, A. (2003). Temporary threshold shift in military pilots measured using conventional and extended high-frequency audiometry after one flight. International Journal of Audiology, 42(1), 29-33.

Kuronen, P., Toppila, E., Starck, J., Pääkkönen, R., \& Sorri, M. J. (2004). Modelling the risk of noise-induced hearing loss among military pilots. International Journal of Audiology, 43(2), 79-84.

Lass, N.J. \& Woodford, C. M. (2007). Hearing Science Fundamentals. (1st ed.), (pp.1-256). Elsevier Mosby.

Lee, J. H., Jang, H. S., \& Chung, H. J. (2005). A study on frequency characteristics of Korean phonemes. Audiology, 1(1), 59-66.

Lee, J. H., Kim, J. S., Oh, S. Y., Kim, K. S., \& Cho, S. J. (2003). Effects of age on hearing thresholds for normal adults. Korean Journal of Audiology, $7(1), 15-23$.

Lee, W. J. (2020, July 27). Helicopter UH-1H Retired after 52 Years Mission and the Helicopter 'Surion' will Now Take Over its Duty. News1. Retrieved from https://www.news1.kr/articles/?4007608.

Lee, Y. R., Choi, J. H., Lee, Y. J., Oh, J. M., Song, H. J., \& Youn, N. H. (2017). Effect of cigarette smoking on hearing impairment in Korean adults over 40 years-old: Based on the data from Korean National Health and Nutrition Examination survey, 2013. Korean Journal of Family Practice, 7(6), 892-897.

Lim, J., Lee, W. Y., \& Yang, S. M. (2011). The hearing loss in Korean air force pilots. Korean Journal of Aerospace and Environmental Medicine, 21(2), 34-37.

Lindgren, T., Wieslander, G., Dammström, B. G., \& Norbäck, D. (2009). Tinnitus among airline pilots: prevalence and effects of age, flight experience, and other noise. Aviation, Space, and Environmental Medicine, 80(2), 112-116.

MacGregor, A. J., Joseph, A. R., \& Dougherty, A. L. (2020). Prevalence of tinnitus and association with self-rated health among military personnel injured on combat deployment. Military Medicine, 185(9-10), el608e1614.

Moon, I. S. (2006). Noise induced hearing loss caused by gunshot in military service. Korean Journal of Otorhinolaryngology-Head and Neck Surgery, 49(9), 887-891.

Moore, B. A., Moring, J. C., Hale, W. J., \& Peterson, A. L. (2019). Incidence rates of tinnitus in active duty military service members between 2001 and 2015. American Journal of Audiology, 28(4), 866-876.

Orsello, C. A., Moore, J. E., \& Reese, C. (2013). Sensorineural hearing loss incidence among U.S. military aviators between 1997 and 2011. Aviation, Space, and Environmental Medicine, 84(9), 975-979.

Owen, J. P. (1996). A survey of hearing loss in Army aircrew. Occupational Medicine (Oxford, England), 46(1), 53-58.

Park, I. J. \& Kim, S. W. (2003) The analysis of hearing loss of pilots in the air force. Cheongju: The journal of Korean Military Medical Association, 34(1), 142-150.

Raynal, M., Kossowski, M., \& Job, A. (2006). Hearing in military pilots: one-time audiometry in pilots of fighters, transports, and helicopters. Aviation, Space, and Environmental Medicine, 77(1), 57-61.

Sataloff, J., Sataloff, R. T., Menduke, H., Yerg, R., \& Gore, R. P. (1984). Hearing loss and intermittent noise exposure. Journal of Occupational Medicine: Official Publication of the Industrial Medical Association, 26(9), 649-656. 
Son, B. S., Kang, M. S., Park, J. A., Jang, B. K., \& Lee, J. W. (2000). Hearing threshold level by age of a male Korean. Journal of Korean Public Health Association, 26(4), 470-483.

Toppila, E., Pyykkö, I., Starck, J., Kaksonen, R., \& Ishizaki, H. (2000). Individual risk factors in the development of noise-induced hearing loss. Noise and Health, 2(8), 59-70.

United States Government US Army. (2018). Training Circular TC 3-04.93 Aeromedical Training for Flight Personnel August 2018. (8th ed.), (pp.1-
170). California, CA: CreateSpace.

Wagstaff, A. S. \& Årva, P. (2009). Hearing loss in civilian airline and helicopter pilots compared to air traffic control personnel. Aviation, Space, and Environmental Medicine, 80(10), 857-861.

Yoon, W. K. (2020, June 5). The Noise War Continues over 60 Years in Yulmun-ri, Sinbuk-eup, Chuncheon City. ms Today. Retrieved from https:// www.mstoday.co.kr/news/articleView.html?idxno=36303. 